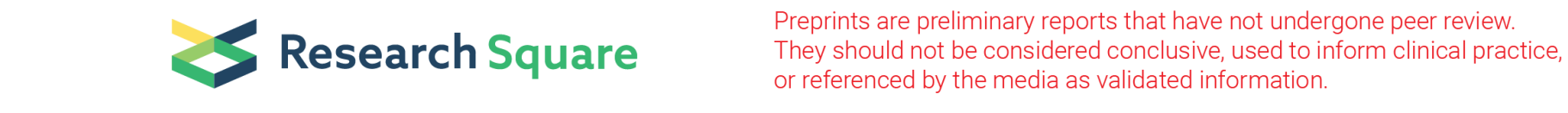

\title{
Evaluation of Housekeeping Gene Expression Stability in Carnation (Dianthus caryophyllus)
}

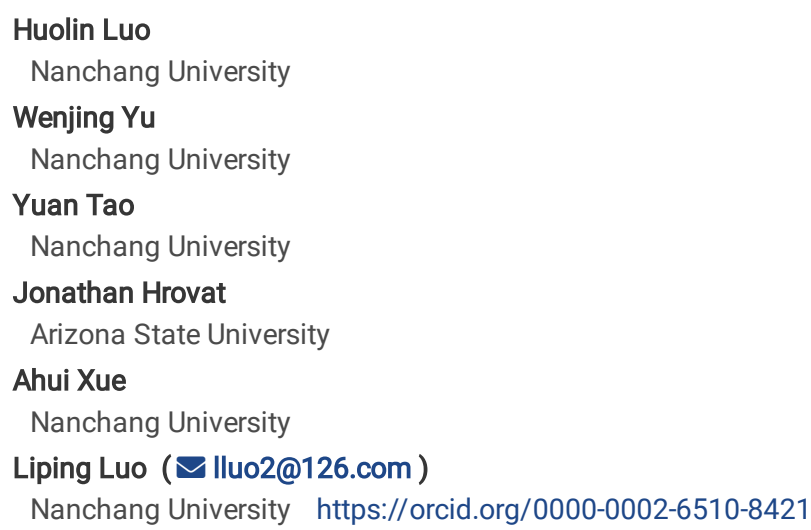

Research

Keywords: Carnation, geNorm, NormFinder, Quantitative real-time PCR, Reference gene

Posted Date: February 25th, 2020

DOl: https://doi.org/10.21203/rs.2.24535/v1

License: (c) (1) This work is licensed under a Creative Commons Attribution 4.0 International License. Read Full License 


\section{Abstract}

Background: The real-time quantitative reverse transcription PCR (RT-qPCR) is widely used for gene expression analysis, owing to its advantages of high specificity, sensitivity and repeatability. A suitable reference gene is an absolute prerequisite for accurate normalization, nevertheless, the frequently-used reference gene was reported unstable under different experimental conditions and causes failure to correctly analyze the expression of the interested gene. Therefore, it is vital to systematically evaluate the expression stability of these candidate reference genes before performing RT-qPCR.

Results: In this study, two computational statistical methods were used, including geNorm and NormFinder, in order to determine the expression stability of 12 frequently-used reference genes in Dianthus caryophyllus across different experimental conditions. The results show that the expression stability of candidate genes varies greatly in different sample pools, which again proves the instability of these common housekeeping gene expressions. In general, the expression of UBQ10 (ubiquitin10), EF1a (elongation factor 1A) and TIP41 (TIP41-like family protein) were relatively stable under different experimental conditions, while the expression stability of 18S (18S Ribosome RNA), TIF5A (translation initiation factor 5A) and PP2A (protein phosphatase $2 \mathrm{~A}$ ) were relatively poor.

Conclusion: EF1a, TIP41 and UBQ10 were considered the most appropriate reference genes when all samples were put together, while UBQ10 was most stable in exogenous hormone treatments. TUB and UBQ10 can be used as reliable internal control genes under stress, while CYP and TUA can act as reliable internal controls in different tissues. This is the first systematic study of selection of reference genes in Carnation, and will benefit future expression studies in this crop.

\section{Background}

Real-time quantitative reverse transcription PCR (RT-qPCR) is a method developed from traditional PCR technology that has strong specificity, sensitivity and high throughput for the quantification of nucleic acids $[2,8]$. It has been widely used in molecular biology, medicine and other basic research fields, especially in gene function studies, strain identification, and the inspection and quarantine of animal- and plant-derived pests and diseases[21, 25, 27]. Due to its high sensitivity, many factors could affect the accuracy of RT-qPCR. Incorrect sampling, loss in RNA extraction, RNA quality, and PCR amplification efficiency are all possible causes for serious errors in gene expression analysis results. Therefore, introducing the appropriate reference gene is the most important prerequisite for accurate analysis of RT-qPCR results[1, 32].

An ideal internal reference gene should have the following characteristics: (1) stable expression in different tissues and developmental stages, and not affected by experimental treatment; (2) cannot be a pseudogenes; (3) The expression level should be in a suitable range ( $15<\mathrm{Cq}<30$ ), not too low or too high[22, 29]. ACTIN, glyceraldehyde-3-phosphate dehydrogenase (GAPDH), elongation factor 1-alpha (EF1a), and ubiquitin-conjugating enzyme (UBC) are commonly used internal reference genes in plant gene expression analysis experiments [17].

In recent years, there have been reports involving expression stability evaluations of housekeeping genes in plants with high economic value, such as rice, radish, tomato, pear, and kumquat[3, 7, 16, 31]. For example, Li found that elF-4a and ACT1 were most stably expressed in rice[18], while in sweet potato, the two genes had unstable expression and the suitable reference genes were ADP-ribosylation factor (ARF), ubiquitin extension protein (UBI) and cytochrome c oxidase subunit $\mathrm{Vc}$ (COX) [23]. These reports once again demonstrated that the stability of the internal reference genes varied across different plants, different experimental conditions, and different developmental stages.

Carnations (Dianthus caryophyllus), one of the world's top 4 cut flowers, belongs to the genus Dianthus of Caryophyllaceae, with high ornamental and economic value [19]. Up to now, the evaluation of housekeeping gene expression stability in carnations has not been reported. Therefore, in this experiment, we systematically evaluated the stability of 12 commonly used internal reference genes under different experimental conditions, which will help us to obtain accurate RT-qPCR results in carnations.

\section{Materials And Methods Plant materials}

D. caryophyllus 'Hongniang' served as the plant material. The seeds were provided by Jiangxi Key Laboratory of Plant Resources, sowed in pots, covered with about $2 \mathrm{~cm}$ of soil, and germinated in an artificial climate chamber at $25^{\circ} \mathrm{C}$. One week after germination, the culture conditions were $28{ }^{\circ} \mathrm{C}$ with 14 hours of light and $22^{\circ} \mathrm{C}$ with 10 hours of darkness. The seedlings were further cultivated to flowering, and the roots, leaves, sepal, petals, stamens, pistils and flower buds of different periods were taken, frozen via liquid nitrogen, and stored in a $-70{ }^{\circ} \mathrm{C}$ refrigerator for future use.

Abiotic stress treatment mainly includes drought, salt, extreme temperatures and heavy metal treatments. Hormone treatment included naphthaleneacetic acid (NAA), 6-benzylaminopurine (6-BA), gibberellic acid (GA) and abscisic acid (ABA) processing. A cold and heat stress was implemented by exposing the carnation to 4 or $42^{\circ} \mathrm{C}$ for 24 hours. For other treatments, such as salt, drought, heavy metals, and hormone treatment, the seedlings are placed in $\mathrm{NaCl}$, mannitol, CuSO4, $\mathrm{CrCl} 3, \mathrm{ABA}, \mathrm{NAA}, 6-\mathrm{BA}$, and GA solution for 24 hours, after that, roots and leaves were sampled, and the solution concentration is $100 \mathrm{mM}[26]$

\section{Primer Design}


12 candidate internal control genes, including TIF5A (translation initiation factor 5A), UBQ10, TIP41 (TIP41-like family protein ), CYP, glyceraldehyde-3phosphate dehydrogenase gene (GAPDH), elongation factor 1 alpha (EF1a), actin gene (ACT), 18S Ribosome RNA (18S), a tubulin and $\beta$-tubulin gene (TUA, TUB), adenosylmethionine decarboxylase gene (SamDC), and protein phosphatase 2A (PP2A) were selected to determine possible reference genes that exhibited stable expression patterns. These 12 genes were selected because they were commonly used internal housekeeping genes, and their sequences were available in NCBI. The sequence was downloaded from NCBI and primers for RT-qPCR were selected using Primer3 software (v0.4.0) with annealing temperatures of 57 to $68^{\circ} \mathrm{C}$, primer lengths of $18-20 \mathrm{bp}$, and approximately $50 \%$ GC content. A $60-200$ bp amplicon length is used to ensure sufficient amplification efficiency and reduce the impact of RNA integrity on the quantitation process. The primer sequences, amplicon sizes and melting points of all PCR products are shown in Table 1.

Table 1

RT-qPCR primer sequences and the characteristics of the resulting amplicons obtained from Carnation.

\begin{tabular}{|c|c|c|c|c|c|c|c|c|}
\hline Name & $\begin{array}{l}\text { Accession } \\
\text { No. }\end{array}$ & Forward primer $\left(5^{\prime}-3^{\prime}\right)$ & Reverse primer $\left(5^{\prime}-3^{\prime}\right)$ & $\begin{array}{l}\text { Primer } \\
\operatorname{TM}\left({ }^{\circ} \mathrm{C}\right)\end{array}$ & $\begin{array}{l}\text { Product } \\
\text { Size(bp) }\end{array}$ & $\begin{array}{l}\text { Product } \\
\operatorname{TM}\left({ }^{\circ} \mathrm{C}\right)\end{array}$ & Efficiency & $\mathbf{R}^{2}$ \\
\hline EF1a & FY400608.1 & ACCCCGACAAGATCCCATTT & TGGTCAAGGGCCTCAAGTAG & $59 / 59$ & 115 & 85 & 1.992 & 0.994 \\
\hline TIP41 & FY397769.1 & GACACTCGTATGCATTGCGT & CTCGAACTGATGACGCTTGG & $59 / 59$ & 152 & 84 & 1.987 & 0.996 \\
\hline TUB & FY383542.1 & GAGCGTTTGTGACATACCCC & GCCTTACGCCTGAACATAGC & $59 / 59$ & 126 & 83 & 2.021 & 0.997 \\
\hline UBQ10 & FY401337.1 & CCATTTGGTGTTGCGTCTCA & TCGCTGCTCTCCACTTCC & $59 / 59$ & 90 & 82 & 1.998 & 0.998 \\
\hline CYP & FY390976.1 & TCTACGGCGCGAAATTCAAG & TCACGACGTCCAATCCTTCA & $59 / 59$ & 186 & 83.5 & 2.014 & 0.999 \\
\hline TUA & FY387136.1 & TCTACGGCGCGAAATTCAAG & TCACGACGTCCAATCCTTCA & $59 / 59$ & 186 & 82.5 & 1.984 & 0.998 \\
\hline GAPDH & FY396181.1 & GGTTTGGCATTGTTGAGGGT & TGCTGCTGGGAATGATGTTG & $58 / 58$ & 132 & 81 & 2.028 & 0.996 \\
\hline SamDC & FY400181.1 & AAACCAACTACGACGACCCT & ACGATGCCTTCTCCTTGTCA & $59 / 59$ & 72 & 84.5 & 2.022 & 0.998 \\
\hline PP2A & FY383979.1 & TCGAGCAGTTGATGGAGTGT & АСТСТTСAАССAAAACCGCC & $59.03 / 58.97$ & 87 & 83 & 1.988 & 0.995 \\
\hline ACT & FY386099.1 & GGACTCTGGTGATGGTGTCA & CAATGTACGCCAGCTTCTCC & $59.02 / 58.99$ & 200 & 83.5 & 2.018 & 0.994 \\
\hline TIF5A & AF296081.1 & GGCGGGGAAAGACTTGATTC & AGCTTCTACTTGCCACCACT & $58.90 / 58.94$ & 93 & 82.5 & 1.995 & 0.993 \\
\hline $18 \mathrm{~S}$ & FY386615.1 & TACAAAGGGCAGGGACGTAG & AGGCCCGGGTAATCTTTGAA & $59.10 / 59.00$ & 126 & 83.5 & 2.009 & 0.994 \\
\hline
\end{tabular}

\section{Total RNA Extraction And cDNA Synthesis}

According to the manufacturer's protocol, the total RNA was isolated in samples using the Eastep® Super Total RNA Extraction Kit (TaKaRa, Japan), and the genomic DNA was removed by RNase-free DNase I (TaKaRa, Japan). The purity and integrity of RNA were determined by spectrophotometry and agarose electrophoresis, respectively. cDNA synthesis was carried out according to the PrimeScriptTM RT Reagent Kit with gDNA Eraser [TaKaRa] operating instructions, in the presence of 500 ng RNA, 2.5 M oligo-(dT).

\section{Real-time PCR}

RT-qPCR was performed using an CFX Connect ${ }^{\text {TM }}$ Real-Time PCR Detection System and a TB Green® Premix Ex TaqTM II Kit. The RT-qPCR reaction was carried out in a $20 \mathrm{uL}$ reaction, including $1.6 \mu \mathrm{l}$ of cDNA, $0.8 \mu \mathrm{l}$ of each primer $(10 \mu \mathrm{M})$, and $10.0 \mu \mathrm{l}$ of $2 \times$ TB Green Premix Ex Taq II (Tli RNaseH Plus). In addition, reactions without templates or primers serverd as a negative control to exclude possible contamination. The thermal cycle program was set as the initial polymerase activation step, which was carried out for 30 seconds at $95^{\circ} \mathrm{C}$, and then 40 cycles, including 15 seconds at $94{ }^{\circ} \mathrm{C}$ for template denaturation, 15 seconds at $55-65^{\circ} \mathrm{C}$ for annealing, and 45 seconds at $72{ }^{\circ} \mathrm{C}$ for extension and fluorescence detection. All samples were amplified in triplicate. The specificity of RT-qPCR was confirmed by agarose electrophoresis and dissociation curve analysis. The cycle threshold for each reaction (Cq, the first cycle of the signal over the background) was automatically determined, by default parameters of the CFX Connect ${ }^{\text {TM }}$ Real-Time PCR Detection System device.

\section{Data Analysis}

Based on the original fluorescence data obtained from Applied Biosystems 7300 Real-Time PCR System equipment, the Lin-RegPCR program was used to calculate the RT-qPCR efficiency and the correlation coefficients for each gene. The Cq value [20] used in the analysis represents the average of 6 values (3 biological repetition and 3 technical repetition) and a comparative Cq method was used to transform these values to relative quantities, according to the instructions of geNorm v3.5 and NormFinder v0.953 (www.gene-quantifification.info) [29].

\section{Results}




\section{Expression profiles of reference genes}

The Cq value was negatively correlated with the initial template quantity of RT-qPCR [11]. The higher the Cq value, the less the gene content. As shown in Fig. 1, the gene with the highest expression level was $18 \mathrm{~S}$ (the average Cq value of the gene was the lowest), while the lowest expressed gene was ACT. Although the amount of RNA initially added in the RT-qPCR reaction was the same, the Cq value of each gene varied considerably across different experimental conditions, indicating that there were no genes with absolutely stable expression pattern (Fig. 1). Among all the genes, the largest change in Cq value was ACT, which seemed to suggest that the gene expression was the least stable. TIP41 had the smallest change in Cq value, indicating that the expression of this gene may be relatively stable. However, the stability of gene expression ultimately required further evaluation, and reliable reference genes were evaluated according to the specific situation.

\section{geNorm Analysis}

geNorm software is a commonly used tool for evaluating the stability of internal reference genes. It is a VBA macro program that is mainly based on the Microsoft Excel platform. The algorithm performs analyses by introducing the stability value $M$ of the internal reference gene expression, and the magnitude of the $\mathrm{M}$ value is negatively correlated with the stability of the gene; the smaller the $\mathrm{M}$ value, the more stable the gene [12]. As shown in Table 2, when looking at the expression data set as a whole, EF1a and TIP41 showed the lowest M values therefore, the two genes could be reliable internal control genes in this sample pool, while across different tissues, TUA and CYP exhibited the most stable expression pattern. Under the hormone treatment of NAA, 6-BA and GA, the most stable genes in leaves were TIP41 and TUA, while in roots the available internal housekeeping genes were EF1a and 18S. When carnations encountered abiotic stress, the expression of UBQ10 and EF1a were the most stable in leaves, while TUB and TIP41 were stable in roots.

Table 2

Ranking of the 12 carnation reference genes as calculated by geNorm.

\begin{tabular}{|c|c|c|c|c|c|c|c|c|c|c|c|c|}
\hline \multirow[t]{2}{*}{ Rank } & \multicolumn{2}{|c|}{ All samples } & \multicolumn{2}{|c|}{ Different tissues } & \multicolumn{2}{|c|}{$\begin{array}{l}\text { Leaves treated } \\
\text { with } \\
\text { phytohormone }\end{array}$} & \multicolumn{2}{|c|}{$\begin{array}{l}\text { Roots treated with } \\
\text { phytohormone }\end{array}$} & \multicolumn{2}{|c|}{$\begin{array}{l}\text { Leaves treated with } \\
\text { stress }\end{array}$} & \multicolumn{2}{|c|}{$\begin{array}{l}\text { Roots treated with } \\
\text { stress }\end{array}$} \\
\hline & Gene & $\begin{array}{l}\mathrm{M} \\
\text { value }\end{array}$ & Gene & $\begin{array}{l}\mathrm{M} \\
\text { value }\end{array}$ & Gene & $\begin{array}{l}\mathrm{M} \\
\text { value }\end{array}$ & Gene & M value & Gene & M value & Gene & $M$ value \\
\hline 1 & EF1a & 0.539 & TUA & 0.187 & TUA & 0.105 & EF1a & 0.043 & UBQ10 & 0.173 & TUB & 0.178 \\
\hline 2 & TIP41 & 0.539 & CYP & 0.187 & TIP41 & 0.105 & $18 \mathrm{~S}$ & 0.043 & EF1a & 0.173 & TIP41 & 0.178 \\
\hline 3 & TUB & 0.560 & TIP41 & 0.365 & EF1a & 0.175 & UBQ10 & 0.077 & TIP41 & 0.198 & UBQ10 & 0.478 \\
\hline 4 & UBQ10 & 0.575 & TUB & 0.462 & UBQ10 & 0.195 & TIF5A & 0.178 & TUB & 0.237 & TUA & 0.630 \\
\hline 5 & CYP & 0.649 & EF1a & 0.525 & SamDC & 0.260 & TIP41 & 0.236 & ACT & 0.290 & CYP & 0.699 \\
\hline 6 & TUA & 0.676 & GAPDH & 0.579 & TIF5A & 0.293 & ACT & 0.290 & GAPDH & 0.348 & TIF5A & 0.754 \\
\hline 7 & GAPDH & 0.890 & UBQ10 & 0.642 & TUB & 0.342 & TUA & 0.350 & TIF5A & 0.433 & GAPDH & 0.816 \\
\hline $\begin{array}{l}8 \\
9 \\
10 \\
11 \\
12\end{array}$ & $\begin{array}{l}\text { SamDC } \\
\text { PP2A } \\
\text { ACT } \\
\text { TIF5A } \\
\text { 18S }\end{array}$ & $\begin{array}{l}1.017 \\
1.106 \\
1.176 \\
1.244 \\
1.303\end{array}$ & $\begin{array}{l}\text { ACT } \\
\text { SamDC } \\
\text { 18S } \\
\text { TIF5A } \\
\text { PP2A }\end{array}$ & $\begin{array}{l}0.733 \\
0.828 \\
0.941 \\
1.069 \\
1.200\end{array}$ & $\begin{array}{l}\text { PP2A } \\
\text { GAPDH } \\
\text { CYP } \\
\text { ACT } \\
18 S\end{array}$ & $\begin{array}{l}0.434 \\
0.498 \\
0.572 \\
0.655 \\
0.753\end{array}$ & $\begin{array}{l}\text { GAPDH } \\
\text { TUB } \\
\text { SamDC } \\
\text { CYP } \\
\text { PP2A }\end{array}$ & $\begin{array}{l}0.401 \\
0.454 \\
0.510 \\
0.565 \\
0.634\end{array}$ & $\begin{array}{l}\text { PP2A } \\
\text { 18S } \\
\text { SamDC } \\
\text { CYP } \\
\text { TUA }\end{array}$ & $\begin{array}{l}0.498 \\
0.565 \\
0.623 \\
0.679 \\
0.738\end{array}$ & $\begin{array}{l}\text { EF1a } \\
\text { ACT } \\
\text { PP2A } \\
\text { SamDC } \\
\text { 18S }\end{array}$ & $\begin{array}{l}0.865 \\
0.956 \\
1.056 \\
1.126 \\
1.299\end{array}$ \\
\hline
\end{tabular}

Generally speaking, when performing RT-qPCR analyses, increasing the number of internal reference genes may improve the accuracy of the experiment. In order to determine the appropriate number of internal reference genes under certain experimental conditions, geNorm software was used to analyze the variation of pairs of internal reference genes to calculate the appropriate number of genes. Researchers typically chose 0.15 as the critical value for selecting the best internal parameter genes [29]. For example, in all samples, the value of $V_{2 / 3}$ is higher than 0.15 , indicating that the first two reference genes are not enough to accurately quantify the results, while $V_{3 / 4}$ is lower than 0.15 , indicating that the first three reference genes can be used as internal reference genes to obtain more accurate results. In addition, $V_{4 / 5}$ was higher than 0.15 , and if you added the fourth-ranked gene as an internal reference gene, it would not only increased the cost of the test, but would also negatively affect the accuracy of the results (Fig. 2). Certainly, 0.15 was not an absolute critical value. When selecting a critical value, many factors needto be considered such as sample size and the variation range [10, 29]. In addition, the number of internal reference genes should also consider the test cost and the required test accuracy. As shown in Fig. 2 , in different tissues (hormone-treated roots, hormone-treated leaves and stressed leaves) the first two internal reference genes was sufficient to obtain accurate results of gene expression analysis. In stress-treated roots, four internal reference genes need to be used to correct the fluorescence quantitative data. 


\section{NormFinder Analysis}

NormFinder Analysis is a alternative tool that is commonly used to screen stable internal reference genes that, similar to geNorm, is a VBA macro program written on the Microsoft Excel platform. By comparing the expression variation of each gene, the expression stability coefficient (expression values) of each gene under certain experimental conditions was calculated, and this coefficient was also negatively correlated with the stability of gene expression $[4,9,13]$. In addition, the software can group samples over a wide range of samples in order to obtain more accurate results. In this trial, when analyzing all the samples, the 33 samples were divided into two groups: untreated and treated. According to the analysis of Normfinder software [15] (Table 3), UBQ10 and EF1a exhibited the most stable expression pattern, whether grouped or not, although the order of other genes is slightly different. GAPDH and TUB expressed stable across different tissues, followed by EF1 $\mathrm{a}$ and UBQ10. Under hormone treatment, SamDC and UBQ10 were the most stable genes in leaves, while UBQ10 and 18S were the suitable reference genes in roots. For abiotically stressed leaves the reliable housekeeping genes were UBQ10 and EF1a, while those in stressed roots, UBQ10 and ACT, expressed more stable.

Table 3

Ranking of the 12 carnation reference genes as calculated by NormFinder.

\begin{tabular}{|c|c|c|c|c|c|c|c|}
\hline \multirow[t]{2}{*}{ Rank } & \multicolumn{2}{|l|}{ All samples } & \multirow[t]{2}{*}{ Different tissues } & \multirow{2}{*}{$\begin{array}{l}\text { Leaves treated with } \\
\text { phytohormone }\end{array}$} & \multirow{2}{*}{$\begin{array}{l}\text { Roots treated with } \\
\text { phytohormone }\end{array}$} & \multirow{2}{*}{$\begin{array}{l}\text { Leaves treated } \\
\text { with stress }\end{array}$} & \multirow{2}{*}{$\begin{array}{l}\text { Roots treated } \\
\text { with stress }\end{array}$} \\
\hline & No.of subgroups & 2 subgroups & & & & & \\
\hline 1 & UBQ10 & UBQ10 & GAPDH & SamDC & UBQ10 & UBQ10 & UBQ10 \\
\hline 2 & EF1a & EF1a & TUB & UBQ10 & $18 S$ & EF1a & ACT \\
\hline 3 & TIP41 & TIP41 & EF1a & TIP41 & TIP41 & PP2A & TUB \\
\hline 4 & TUB & TUB & UBQ10 & CYP & EF1a & TUB & TIP41 \\
\hline 5 & TUA & TUA & TIP41 & TUA & TUA & ACT & CYP \\
\hline 6 & CYP & CYP & CYP & PP2A & TUB & GAPDH & TIF5A \\
\hline 7 & GAPDH & GAPDH & TUA & TUB & TIF5A & TIP41 & TUA \\
\hline 8 & SamDC & SamDC & ACT & GAPDH & CYP & TUA & PP2A \\
\hline 9 & ACT & ACT & TIF5A & EF1a & ACT & CYP & EF1a \\
\hline 10 & PP2A & PP2A & $18 \mathrm{~S}$ & TIF5A & PP2A & $18 S$ & GAPDH \\
\hline 11 & TIF5A & TIF5A & SamDC & ACT & GAPDH & SamDC & $18 \mathrm{~S}$ \\
\hline 12 & $18 \mathrm{~S}$ & $18 \mathrm{~S}$ & PP2A & $18 \mathrm{~S}$ & SamDC & TIF5A & SamDC \\
\hline
\end{tabular}

\section{Discussion}

Because of its high specificity, sensitivity and high throughput, RT-qPCR has been widely used to analyze gene expression, animal and plant viruses, and much more $[5,28,33]$. However, if the unstable internal reference gene was selected in the experiment, it will seriously affect the accuracy of the experimental results, and even possibly lead to the completely opposite results. An absolutely stable internal reference gene does not exist; even if it is the same gene, its expression stability will change in different species, different growth stages and different treatments. For example, act11 has been proved to be a stably expressed gene in Soybeans [14]. However, the expression stability of act11 in rice is not reliable [16], while in ryegrass, its stability is the lowest [6], similar to the results of this experiment.

Many different softwares were used to evaluate the stability of gene expression [24], and the softwares were based on distinct principles. Which software was authoritative has not been determined. Therefore, in this experiment, the two most commonly used softwares, geNorm and NormFinder, were selected evaluate the gene expression stability. It was shown that under most experimental conditions, the output of these two softwares was generally consistent. However, in different tissues and treated roots, gene stability was quite different. The difference in results may be due to the difference in algorithms between the two tools, or the existence of co-regulation between genes, because the results of geNorm would be interfered by gene co-regulation, while the results from NormFinder will not [30]. In order to test whether there was co-regulation in these genes, one of the 12 candidate genes was removed one by one, and then the data was introduced into the geNorm software for calculation. This was done in order to see whether there was significant changes in the rank of other genes. The results showed that when removing any gene, there was no significant change in the remaining gene sequence. Therefore, the results of the two tools were different only because of their different algorithms [7, 13, 28].

As shown in Tables 2 \& 3, the order of stability of candidate reference gene expression was not consistent under different experimental conditions in Carnations. For example, EF1 a was the most stable internal control gene when looking at the expression data set as a whole, while under stress treatments, other genes exhibited more stable expression patterns, which proved again that the stability of genes was different depending on the 
treatments or tissues being used. Before selecting the internal control genes, we should consider the development stages, tissues and treatment methods of plants because the stability of gene expression was related to the experimental conditions.

\section{Conclusion}

To the best of our knowledge, this study is the first to analyze qPCR reference genes of carnation under different conditions. Based on the analysis results of geNorm and NormFinder, when looking at the expression data set as a whole, three internal reference genes are needed to get more accurate analysis results. They were EF1a, TIP41 and UBQ10, while in in stressed roots, the combination of TUB, TIP41 and UBQ10 could get more practical results. In stressed leaves, UBQ10 and EF1a was sufficient to normalize RT-qPCR data. Across different tissues, the expression stability CYP and TUA ranked well. In hormone-treated roots, $18 \mathrm{~S}$ and UBQ10 showed stable gene expression patterns, while UBQ10 and EF1a were stable in hormone-treated leaves (Table 4).

Table 4

Comprehensive evaluation of the expression stability of candidate reference genes.

\begin{tabular}{|c|c|c|c|c|c|c|}
\hline Rank & All samples & Different tissues & $\begin{array}{l}\text { Leaves treated with } \\
\text { phytohormone }\end{array}$ & $\begin{array}{l}\text { Roots treated with } \\
\text { phytohormone }\end{array}$ & $\begin{array}{l}\text { Leaves treated } \\
\text { with stress }\end{array}$ & $\begin{array}{l}\text { Roots treated } \\
\text { with stress }\end{array}$ \\
\hline 1 & EF1a & CYP & TIP41 & $18 \mathrm{~S}$ & UBQ10 & TUB \\
\hline 2 & TIP41 & TUA & UBQ10 & UBQ10 & EF1a & TIP41 \\
\hline 3 & UBQ10 & TUB & SamDC & EF1a & TUB & UBQ10 \\
\hline 4 & TUB & TIP41 & TUA & TIP41 & TIP41 & CYP \\
\hline 5 & TUA & GAPDH & EF1a & TIF5A & ACT & TUA \\
\hline 6 & CYP & EF1a & TUB & ACT & GAPDH & ACT \\
\hline 7 & GAPDH & UBQ10 & TIF5A & TUA & PP2A & TIF5A \\
\hline 8 & SamDC & ACT & PP2A & TUB & $18 \mathrm{~S}$ & EF1a \\
\hline 9 & PP2A & SamDC & CYP & GAPDH & CYP & PP2A \\
\hline 10 & ACT & $18 S$ & GAPDH & CYP & TUA & GAPDH \\
\hline 11 & TIF5A & TIF5A & ACT & PP2A & TIF5A & SamDC \\
\hline 12 & $18 \mathrm{~S}$ & PP2A & $18 S$ & SamDC & SamDC & $18 \mathrm{~S}$ \\
\hline
\end{tabular}

\section{Declarations}

\section{Authors' contributions}

Liping Luo designed the project while Huolin Luo is the main contributor to the writing of the manuscript. Wenjing Yu collected and prepared samples and contextual data. Yuan Tao and Ahui Xue identified samples. Final manuscript read and endorsed by all authors.

\section{Authors details}

School of Life Science, Nanchang University, Nanchang 330031, Jiangxi, China

Huolin Luo, Wenjing Yu, Yuan Tao, Ahui Xue , Liping Luo

Correspondence to Liping Luo.

\section{Competing interests}

The authors declare that they have no competing interests.

\section{Availability of data and materials}

All data generated or analysed during this study are included in this published article.

\section{Consent for publication}

Not applicable

\section{Ethics approval and consent to participate}

Not applicable 


\section{Funding}

This work was supported by the National Natural Science Foundation of China (No. 31360491), the Jiangxi Natural Science Foundation (No.

20171ACB21014) and the Xiansu Scholars Programme of school of life science, Nanchang university.

\section{Acknowledgements}

Thanks to Jiangxi Key Laboratory of Plant Resources for providing plant materials for this study.

\section{References}

1. Berumen-Varela G, Palomino-Hermosillo YA, Bautista-Rosales PU, Peña-Sandoval GR, López-Gúzman GG, Balois-Morales R. Identification of reference genes for quantitative real-time PCR in different developmental stages and under refrigeration conditions in soursop fruits (Annona muricata $L$.). Scientia Horticulturae. 2020;260: 108893.

2. Bustin SA, Benes V, Nolan T, Pfaffl MW. Quantitative real-time RT-PCR-a perspective. J Mol Endocrinol. 2005;34(3): 597-601.

3. Chi X, Hu R, Yang Q, Zhang X, Pan L, Chen N, Chen M, Yang Z, Wang T, He Y, Yu S. Validation of reference genes for gene expression studies in peanut by quantitative real-time RT-PCR. Mol Genet Genomics. 2012;287(2): 167-176.

4. Cruz F, Kalaoun S, Nobile P, Colombo C, Almeida J, Barros LMG, Romano E, Grossi-de-Sá MF, Vaslin M, Alves-Ferreira M. Evaluation of coffee reference genes for relative expression studies by quantitative real-time RT-PCR. Molecular Breeding. 2009;23(4): $607-616$.

5. da Silva MF, Gonçalves MC, dos Santos Brito M, Nóbile PM, de Andrade LM, Medeiros CN, Creste S, Pinto LR. Reference genes for gene expression studies targeting sugarcane infected with Sugarcane mosaic virus (SCMV). BMC Research Notes. 2019;12(1): 149.

6. Dombrowski JE, Martin RC. Evaluation of reference genes for quantitative RT-PCR in Lolium temulentum under abiotic stress. Plant Science. 2009;176(3): 390-396.

7. Exposito-Rodriguez M, Borges AA, Borges-Perez A, Perez JA. Selection of internal control genes for quantitative real-time RT-PCR studies during tomato development process. BMC Plant Biol. 2008;8(1): 131.

8. Ginzinger DG. Gene quantification using real-time quantitative PCR:an emerging technology hits the mainstream. Experimental hematology. 2002;30(6): 503-512.

9. Gopalam R, Rupwate SD, Tumaney AW. Selection and validation of appropriate reference genes for quantitative real-time PCR analysis in Salvia hispanica. PLoS One. 2017;12(11): e0186978.

10. Gu C, Chen S, Liu Z, Shan H, Luo H, Guan Z, Chen F. Reference gene selection for quantitative real-time PCR in Chrysanthemum subjected to biotic and abiotic stress. Mol Biotechnol. 2011;49(2): 192.

11. Gutierrez L, Mauriat M, Pelloux J, Bellini C, Van Wuytswinkel O. Towards a systematic validation of references in real-time rt-PCR. Plant Cell. 2008;20(7): 1734-1735.

12. Hellemans J, Mortier G, De Paepe A, Speleman F, Vandesompele J. qBase relative quantification framework and software for management and automated analysis of real-time quantitative PCR data[J]. Genome biology. 2007;8(2): R19.

13. Hong SM, Bahn SC, Lyu A, Jung HS, Ahn JH. Identification and testing of superior reference genes for a starting pool of transcript normalization in Arabidopsis. Plant Cell Physiol. 2010;51(10): 1694-1706.

14. Hu R, Fan C, Li H, Zhang Q, Fu YF. Evaluation of putative reference genes for gene expression normalization in soybean by quantitative real-time RTPCR. Bmc Molecular Biology. 2009;10(1): 93.

15. Hu Y, Chen H, Luo C, Dong L, Zhang S, He X, Huang G. Selection of reference genes for real-time quantitative PCR studies of kumquat in various tissues and under abiotic stress. Scientia Horticulturae. 2014;174: 207-216.

16. Jain M, Nijhawan A, Tyagi AK, Khurana JP. Validation of housekeeping genes as internal control for studying gene expression in rice by quantitative real-time PCR. Biochem Biophys Res Commun. 2006; 345: 646-51.

17. Li M Y, Song X, Wang F, Xiong AS. Suitable reference genes for accurate gene expression analysis in parsley (Petroselinum crispum) for abiotic stresses and hormone stimuli[J]. Frontiers in plant science. 2016; 7: 1481.

18. Li Q-F, Sun SSM, Yuan D-Y, Yu H-X, Gu M-H, Liu Q-Q. Validation of Candidate Reference Genes for the Accurate Normalization of Real-Time Quantitative RT-PCR Data in Rice During Seed Development. Plant Molecular Biology Reporter. 2009; 28(1): 49.

19. Lim T K. Dianthus Caryophyllus. Edible Medicinal and Non-Medicinal Plants: Flowers, Vol. 7[J]. 2014: 684-693.

20. Livak KJ, Schmittgen TD. Analysis of relative gene expression data using real-time quantitative PCR and the 2(-Delta Delta C(T)) Method. Methods. $2001 ; 25(4):$ 402-408.

21. Miao Y, Yanhui L, Xun Z, Hu W, Muhammad S, Sha Z, Byung-Rae J, Jianhong L, Xiao-Wei W. Selection and Evaluation of Potential Reference Genes for Gene Expression Analysis in the Brown Planthopper, Nilaparvata lugens (Hemiptera: Delphacidae) Using Reverse-Transcription Quantitative PCR. Plos One. 2014; 9(1): e86503.

22. Migocka M, Papierniak A. Identification of suitable reference genes for studying gene expression in cucumber plants subjected to abiotic stress and growth regulators. Molecular Breeding. 2010; 28(3): 343-357. 
23. Park SC, Kim YH, Ji CY, Park S, Jeong JC, Lee HS, Kwak SS. Stable internal reference genes for the normalization of real-time PCR in different sweetpotato cultivars subjected to abiotic stress conditions. PLoS One. 2012; 7(12): e51502.

24. Pfaffl M W, Tichopad A, Prgomet C, Neuvians TP. Determination of stable housekeeping genes, differentially regulated target genes and sample integrity: BestKeeper-Excel-based tool using pair-wise correlations[J]. Biotechnology letters. 2004; 26(6): 509-515.

25. Silveira ÉD, Alves-Ferreira M, Guimarães LA, da Silva FR, de Campos Carneiro VT. Selection of reference genes for quantitative real-time PCR expression studies in the apomictic and sexual grass Brachiaria brizantha. BMC Plant Biology. 2009; 9(1): 84.

26. Su W, Yuan Y, Zhang L, Jiang Y, Gan X, Bai Y, Peng J, Wu J, Liu Y, Lin S. Selection of the optimal reference genes for expression analyses in different materials of Eriobotrya japonica. Plant Methods. 2019; 15(1): 7.

27. Svingen T, Letting H, Hadrup N, Hass U, Vinggaard AM. Selection of reference genes for quantitative RT-PCR (RT-qPCR) analysis of rat tissues under physiological and toxicological conditions. Peer J. 2015; 3: e855.

28. Tang R, Dodd A, Lai D, McNabb WC, Love DR. Validation of zebrafish (Danio rerio) reference genes for quantitative real-time RT-PCR normalization. Acta Biochim Biophys Sin (Shanghai). 2007; 39(5): 384-390.

29. Vandesompele J, De Preter K, Pattyn F, Poppe B, Van Roy N, De Paepe A, Speleman F. Accurate normalization of real-time quantitative RT-PCR data by geometric averaging of multiple internal control genes. Genome Biology. 2002; 3(7): research0034. 1.

30. Willems E, Mateizel I, Kemp C, Cauffman G, Leyns L. Selection of reference genes in mouse embryos and in differentiating human and mouse ES cells. International Journal of Developmental Biology. 2006; 50 (7): 627-635.

31. Xu Y, Zhu X, Gong Y, Xu L, Wang Y, Liu L. Evaluation of reference genes for gene expression studies in radish (Raphanus sativus L.) using quantitative real-time PCR. Biochem Biophys Res Commun. 2012; 424: 398-403.

32. Ye X, Zhang F, Tao Y, Song S, Fang J. Reference gene selection for quantitative real-time PCR normalization in different cherry genotypes, developmental stages and organs. Scientia Horticulturae. 2015; 181: 182-188.

33. Yee S, Blackall PJ, Turni C. Genetic diversity and toxin gene distribution among serovars of Actinobacillus pleuropneumoniae from Australian pigs. Australian Veterinary Journal. 2018; 96(1-2): 17-23.

\section{Figures}

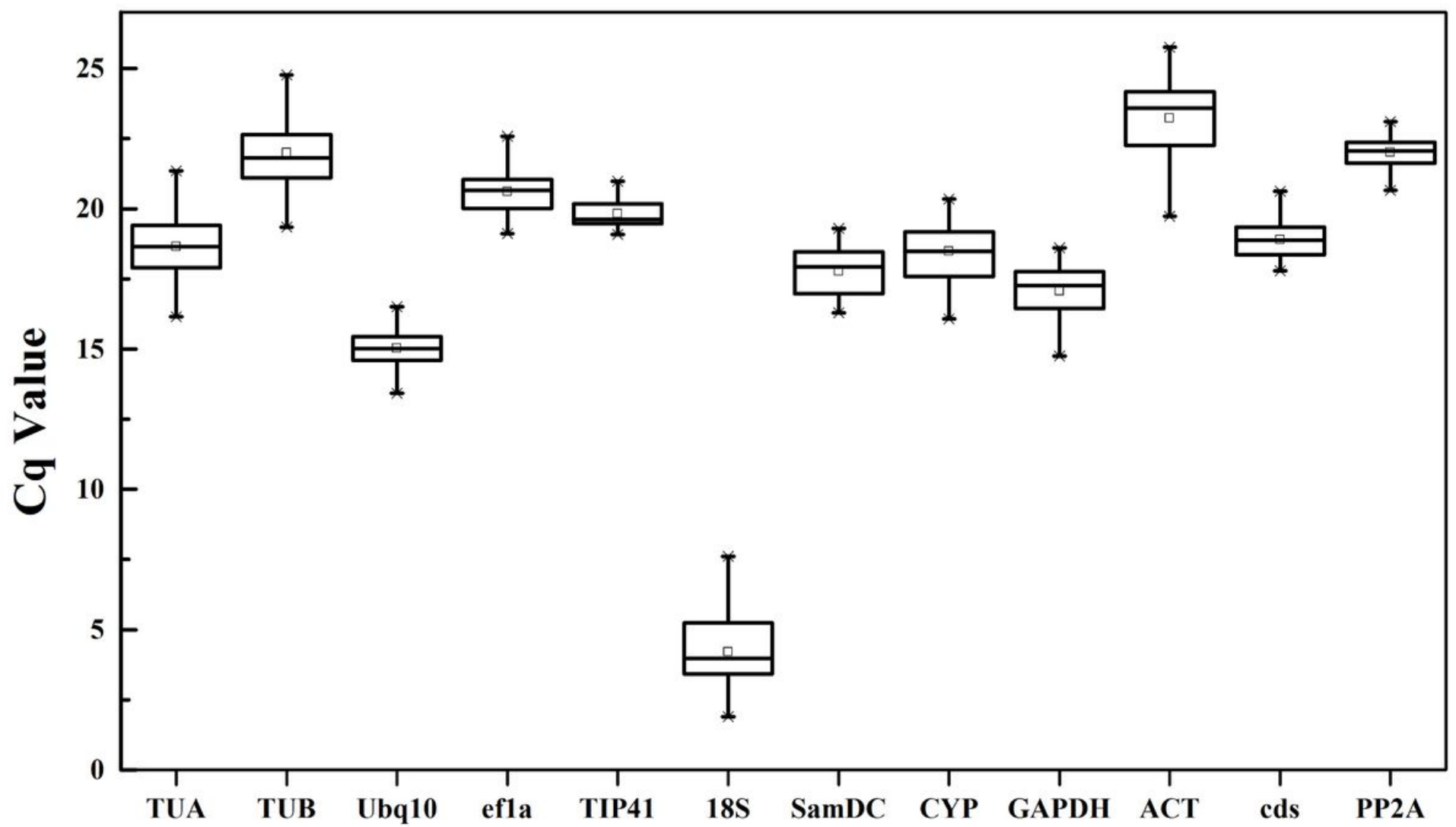

Figure 1

Cq values obtained for each of the twelve reference genes. The line crossing the box indicates the median value. The box defines the 25 and 75 percentiles. Whiskers indicate the maximum and minimum values. 


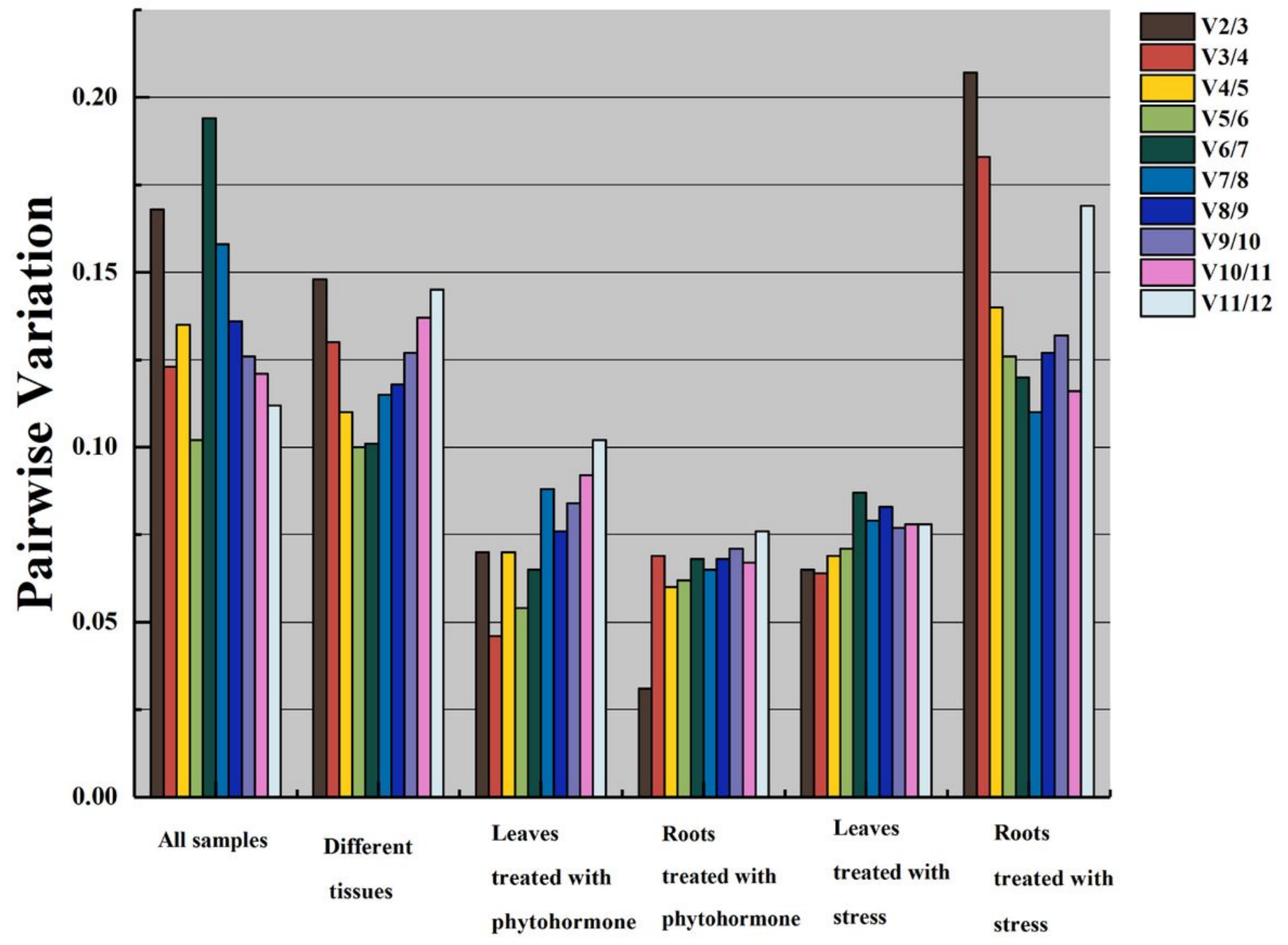

Figure 2

Pairwise variation analysis of the candidate reference genes, as calculated by geNorm 